\title{
MARÍA EUGENIA GÁLVEZ Y SUS TRES CIUDADES
}

Carmen Ruiz Bravo Villasante

En lo más alto de la Facultad de Filosofía y Letras de la Universidad de Madrid de los años sesenta había sólo un aula, que parecía suspendida en el aire: a un lado, las terrazas del edificio; al otro, el amplio espacio de un sector del campus. Con gracia y guasa se llamaba a aquella pequeña clase, en la que sólo cursábamos una asignatura, "la pajarera" o "el palomar". Y allí, ante sus seis o siete alumnos -Aurora Cano, Rosa Montes, Carmen Ruiz, Félix Agüero, Pepe Rodríguez Trobajo, Luis Santiago, Miguel Ángel Chulilla... -, venía, alegre y llena de horizontes, la joven profesora María Eugenia Gálvez a transmitirnos su saber y experiencia de traductora. El curso se dedicó a la obra de Maḥmūd Taymūr, en cuyo lenguaje y recursos se deleitaba, haciendo que nosotros mismos lo pasáramos casi tan bien como ella y ansiáramos saber más árabe del que sabíamos. Quizás entonces podríamos captar mejor los matices de aquel escritor egipcio tan humano, divertido y serio a la vez.

Divertida y seria también era "La Gálvez", que nos dejaba asombrados entonces con varias cosas. Para empezar, con lo cuidada, y un punto coqueta y original, que venía arreglada a la Universidad, algo que alcanzaba hasta a la cartera y carpetas que utilizaba. Esta pulcritud iba acompañada por su dominio del lenguaje y la delectación y naturalidad con que pronunciaba palabras que, de otro modo, habríamos ignorado o se habrían quedado entre las páginas del diccionario. Una de estas palabras fue, por ejemplo, capitidisminuir. Esto era lo que, a su juicio, sucedía con la figura y la obra del autor, que estaban capitidisminuidas, pese a sus evidentes valores literarios y humanos. La clase era, en cierto modo, una reivindicación de justicia cultural, y nosotros nos hacíamos partícipes de aquella idea a medida que íbamos entendiendo mejor el texto. El cuidado de la profesora se extendía hasta los materiales que nos proporcionaba. Apenas había en aquella época, en Madrid, posibilidad de hacerse con libros modernos en árabe; tampoco existían las sencillas y rápidas fotocopias que ahora conocemos. Así que nos proporcionaba unas fotografías de las páginas del texto, de magnífica calidad y en buen número, que se habrían realizado en un laboratorio fotográfico a partir de la obra que ella traducía. Y aunque parezca una minucia, el poseer un texto moderno, en árabe, reproducido a su tamaño y con su tipografía real, producía una curiosa sensación de traslado a aquel país, Egipto, al que estaba vinculada su experiencia.

A relativa poca distancia de la Facultad se hallaba el Instituto Hispano-Árabe de Cultura, en una corta calle llamada Límite (hoy, Juan XXIII). Ocupaba una última y tercera planta de un edificio dedicado a instituciones culturales vinculadas al Ministerio de Asuntos Exteriores, con vistas al entorno de árboles de la Ciudad Universitaria madrileña y también, como la 
Facultad, a la Sierra de Guadarrama, a sus nubes, a sus ocasos rojizos. Allí iban nuestros profesores, María Eugenia Gálvez y Pedro Martínez Montávez, que coordinaban y participaban con gran generosidad en las labores de un Seminario de Pensamiento y Literatura Árabes Contemporáneos, donde árabes y españoles confluían. Un día, a través de la puerta entreabierta, vi extendidas sobre las mesas, en ficheros abiertos, los centenares de fichas bibliográficas, temáticas y léxicas, que confeccionaban, y comprendí el enorme e importantísimo esfuerzo de preparación de todo orden que sustentaba aquellas enseñanzas modernas que recibíamos.

Otro día, en una recepción ofrecida en el mismo edificio con motivo de las Jornadas de Estudios Árabes e Islámicos -creo que las realizadas en Toledo-, nos enterábamos de que nuestra profesora se iba a casar o se había casado. Nos alegramos y la vimos bajo una nueva luz, más familiar y próxima, quizá. Y entonces conocimos al Profesor Presedo, con quien en adelante compartiría María Eugenia su vida. Nos invitaron -a nuestro curso, me refiero- un día a su casa en Madrid, creo que por la zona de Prosperidad, no lejos de donde yo vivía. Aquel hombre hablaba con tremenda franqueza, y no sin ironía, de Egipto, país que conocía muy de cerca como arqueólogo; su punto de vista era distinto, pues provenía del ámbito clásico grecolatino, en tanto que nosotros nos situábamos en el árabo-islámico. Era interesante y estimulante oirles hablar acerca de cómo se relacionaban o no los dos planos: el de lo antiguo y lo moderno, lo greco-latino y lo árabo-islámico, desde su común experiencia egipcia y su vida en Madrid. ¡Con qué entusiasmo se defendían esos puntos de vista humanistas... justo en un momento en que se preparaba, en los ámbitos educativos oficiales, una especie de "secuestro" de las materias de latín, griego y árabe!

Cuando ambos se trasladaron a Sevilla, sentimos que se alejaban unos profesores que nos habían brindado, junto al conocimiento, apoyo y amistad. Desde entonces fueron los compañeros de esta Universidad de Sevilla los que los tuvieron más cerca. Ellos han podido comprobar cómo son ciertas esas cualidades que señalaba. Aquí está María Eugenia, casi sin cambiar en lo físico. Aquí ha llevado adelante la tarea iniciada, culminándola con la publicación en Sevilla de su magnífico libro sobre El Cairo de Mahmūd Taymūr. Y aquí supongo yo- habrá seguido desarrollando sus dotes literarias y, quizá, escribiendo. Porque me parece intuir que su extraordinaria sensibilidad, su fácil y elegante pluma y la riqueza de sus vivencias la llevan en esa dirección.

La vinculación de la Dra. Gálvez Vázquez a Sevilla y su Universidad ha sido estrechísima. Desde mi horizonte he pensado sobre la trayectoria de su compromiso intelectual y social, que se puede interpretar como una profunda compenetración con su entorno. Así, estando en Andalucía, se produjo su traslado, con convencimiento y decisión, a la historia y parajes andalusíes, en diversos artículos de investigación e interpretación. Pero la experiencia anterior seguía estando ahí, fuerte, y llamaba. Nada menos que un Premio Nobel a Naguib Mahfuz, a finales de los ochenta, removía las brasas de lo egipcio y de lo moderno. Y María Eugenia Gálvez ha estado aquí pronta a facilitar la comunicación entre pasados y presentes, occidentes y orientes. Y entre esos reacercamientos o reencuentros de lo que nunca se ha perdido, los 
nuestros propios, en varias ocasiones y circunstancias, dentro de este mismo ámbito universitario sevillano.

Sean estas breves palabras, pronunciadas originalmente en tan solemne ocasión como la que nos reunió, un homenaje de reconocimiento y afecto, extensivos a todos cuantos reciben y van a seguir recibiendo el magisterio y la amistad de María Eugenia Gálvez. Al escribir estas líneas me la imagino leyéndolas. En el tiempo transcurrido desde su homenaje hasta ahora ha sobrevenido la pérdida de Presedo, ha acontecido el nacimiento de algún pequeño en la familia... Seguro que todos ellos le devuelven y abren, con nosotros, como una corriente benéfica que lleva hacia los años futuros, un horizonte para sus cualidades.

Madrid, Octubre 2000. 
